\title{
ANALISIS HARGA POKOK PRODUKSI DAN HARGA POKOK PENJUALAN JAGUNG DI KECAMATAN SEKAMPUNG UDIK KABUPATEN LAMPUNG TIMUR
}

\author{
(Determining Production Cost and Determining Selling Cost Analysis of Corn in Sekampung Udik \\ Subdistrict, East Lampung Regency)
}

Fitri Solekhah, Wan Abbas Zakaria, Lina Marlina

\begin{abstract}
Jurusan Agribisnis, Fakultas Pertanian, Universitas Lampung, Jl. Prof. Dr. Soemantri Brojonegoro No. 1 Bandar Lampung 35145, Telp. 085758478166,e-mail: fitrisolekhah05@ gmail.com
\end{abstract}

\begin{abstract}
This research is to find out determining production cost and selling cost of corn and the affect use of various kinds of seed corn in the determining production cost. The research was conducted in July - August and used a survey method in Sidorejo Village, Sekampung Udik Subdistrict, East Lampung Regency. The samples of this research are 52 corn farmers selected randomly. Analysis of data is conducted using the determining production cost, determining selling cost, and one way Anova. Analysis of the cost of goods production used the margin profit of 15 percent. The results showed determining that production cost is Rp1,383.00/kg for Bisi-18, Rp1,379.28/kg for NK-33, Rp1,448.77/kg for Pioneer-27, and Rp1,359.52/kg for DK-95. Determining selling cost with profit margin 15\% for Bisi-18 is Rp1,590.45/kg, Rp1,586.18/kg for NK-33, $R p 1,666.09 / \mathrm{kg}$ for Pioneer-27, and Rp1,560.00/kg for DK-95. The average price received by the farmers as much as Rpl,741.04/kg, It means that farmers have benefit from technicial efficiency of corn farming. The use of various kinds of seeds does not affect determining production cost.
\end{abstract}

Key words: determining production cost, determining selling cost, technicial efficiency of corn

\section{PENDAHULUAN}

Sektor pertanian, kehutanan dan perikanan memberikan sumbangan terbesar pada PDRB Provinsi Lampung tahun 2012-2014. Pada tahun 2014 sektor pertanian, kehutanan dan perikanan memberikan sumbangan terbesar sebesar 32,69 persen. Dari sektor tersebut, subsektor tanaman pangan memberikan sumbangan terbesar yaitu sebesar 11,04 persen. Akan tetapi, sumbangan tersebut mengalami tren yang menurun sejak 2012 sampai 2014 dan mengalami kenaikan pada tahun 2015 (BPS Provinsi Lampung 2016).

Salah satu komoditas pada subsektor tanaman pangan yang berperan penting dalam pembangunan sektor pertanian adalah jagung. Berdasarkan Sinar Tani (2009) dalam Rosalia (2010), jagung merupakan makanan pokok kedua setelah beras, dan merupakan barang substitusi beras dan ubi kayu. Selain menjadi konsumsi langsung, jagung pipilan kering juga dimanfaatkan untuk industri pengolahan, terutama industri pakan ternak. Kebutuhan jagung untuk industri pakan dan industri ternak semakin meningkat, terutama disebabkan oleh semakin berkembangnya industri ternak unggas, seperti industri ternak ayam potong dan ayam petelur (Falatehan dan Wibowo 2008).
Permasalahan komoditas jagung semakin kompleks, karena produksi jagung nasional belum bisa memenuhi kebutuhan dalam negeri, sehingga Indonesia harus melakukan impor jagung. Berdasarkan potensi yang dimiliki Indonesia, dilihat dari luas panen serta produktivitas jagung, sebenarnya Indonesia mampu berswasembada jagung, bahkan mampu menjadi pemasok jagung di pasar dunia. Akan tetapi pada kenyataannya, Indonesia masih mengimpor jagung untuk memenuhi kebutuhan dalam negeri. Harga jagung yang cenderung mengalami fluktuasi membuat petani beralih ke komoditas lainnya yang harganya lebih tinggi dan lebih menguntungkan.

Provinsi Lampung menempati urutan ke-6 sebagai provinsi penghasil jagung terbesar di Indonesia. Produktivitas jagung di Provinsi Lampung pada tahun 2011-2014 mengalami kenaikan terus menerus, akan tetapi pada tahun 2014 produktivitas jagung mengalami penurunan. Daerah penghasil jagung di Kabupaten Lampung Timur terdapat di tiga kecamatan, yaitu Kecamatan Bandar Sribawono, Kecamatan Marga Sekampung dan Kecamatan Sekampung Udik. Produksi jagung di Kecamatan Sekampung Udik pada tahun 2013-2014 mengalami penurunan, sedangkan Kecamatan Bandar Sribawono dan Kecamatan Marga Sekampung mengalami kenaikan. Produksi 
jagung di Kecamatan Sekampung Udik mengalami penurunan, karena banyak petani jagung yang beralih ke usahatani lainnya seperti ubi kayu. Hal ini dikarenakan harga jual ubi kayu (> Rp10.000,00) yang lebih tinggi dibandingkan dengan jagung (Rp2.000,00 - Rp 2.500,00).

Petani jagung di Desa Sidorejo hanya dapat menjual hasil produksinya pada agen atau pedagang pengumpul, karena petani tidak dapat menjual langsung ke pabrik. Alur tataniaga jagung yang panjang inilah yang menyebabkan petani memperoleh harga yang rendah atas hasil produksinya. Akibatnya, Harga Minimum Regional (HMR) jagung yang ditetapkan oleh Gubernur tidak dapat dirasakan oleh petani (Keputusan Gubernur Penetapan HMR Jagung Provinsi Lampung 2010). HMR jagung di Provinsi Lampung tahun 2015 sebesar Rp2.550,00/kg.

Harga jagung di tingkat petani di Provinsi Lampung mengalami fluktuasi setiap bulannya. Harga jagung tersebut berlaku untuk jagung asalan yang memiliki kadar air $28-40$ persen. Risiko harga yang diterima oleh petani terjadi pada saat musim panen jagung. Pada saat musim panen, harga jagung mengalami penurunan disebabkan oleh supply jagung yang melimpah. Pada saat panen tersebut, petani mengalami penurunan penerimaan atas produksi jagung. Apabila petani menyimpan jagung tersebut dengan dikeringkan, petani akan mendapatkan penerimaan yang lebih tinggi apabila dibandingkan dengan harga pada saat panen.

Harga pokok produksi adalah sejumlah biaya yang dikeluarkan dalam suatu proses per produk yang dihasilkan. Harga pokok produksi usahatani jagung merupakan total biaya yang dikeluarkan oleh petani untuk memproduksi jagung per kilogram dalam suatu proses budidaya pada satu musim tanam. Petani jagung sebagai produsen yang memproduksi jagung juga berorentasi pada laba, sehingga tidak terlepas dari masalah pencapaian laba, dan pengembalian modal, serta perhitungan biaya yang telah dikeluarkan untuk membeli benih jagung. Biaya yang telah dikeluarkan tersebut dipakai sebagai elemen perhitungan dalam pembentukan harga pokok produk (Mulyadi 2001). Pemerintah seharusnya mengevaluasi apakah harga minimum yang telah ditetapkan dapat meningkatkan keuntungan usahatani jagung. Petani jagung dalam melakukan usahataninya menggunakan benih yang berbeda-beda.

Hal tersebut akan mempengaruhi biaya produksi yang dikeluarkan serta hasil produksi yang diperoleh antar petani. Berdasarkan latar belakang tersebut, maka tujuan dari penelitian ini adalah mengetahui harga pokok produksi dan penjualan jagung dari berbagai macam jenis benih yang digunakan dan mengetahui apakah ada perbedaan harga pokok produksi dari berbagai macam jenis benih yang digunakan.

\section{METODE PENELITIAN}

Metode penelitian yang digunakan dalam penelitian ini adalah metode survei dan pengamatan langsung di lapangan yang dilakukan di Desa Sidorejo Kecamatan Sekampung Udik Kabupaten Lampung Timur. Data yang digunakan adalah data primer dan data sekunder. Pengumpulan data dilaksanakan dari Bulan Juli 2016 sampai dengan Bulan Agustus 2016.

Populasi sampel yang digunakan adalah petani jagung yang ada di Desa Sidorejo Kecamatan Sekampung Udik Kabupaten Lampung Timur yang tergabung dalam gabungan kelompok tani (Gapoktan) Sumber Makmur Desa Sidorejo. Populasi petani jagung sebanyak 1.747 petani. Responden yang digunakan sebanyak 52 petani jagung (Sugiarto 2005), yang diambil dengan menggunakan metode acak sederhana menggunakan tabel acak.

Metode analisis yang digunakan untuk menjawab tujuan pertama yaitu dengan perhitungan harga pokok produksi dengan menggunakan analisis perhitungan pendapatan total (Tabel 1) serta aturan mark up dan biaya total. Untuk menjawab tujuan kedua yaitu dengan analisis uji beda menggunakan uji one way anova (SPSS 20). Perhitungan harga pokok penjualan menggunakan metode menurut Koutsoyiannis (1979), dengan aturan mark up sebagai berikut:

HPPenjualan $=$ HPProd +15 persen

Margin keuntungan dihitung berdasarkan tingkat suku bunga tahun 2016 (17,50 persen) (BRI 2016) dan tingkat inflasi $(0,70$ persen) (BPS Provinsi Lampung 2016). Margin yang digunakan dalam penelitian ini sama dengan penelitian Putra (2014) tentang sistem penetapan harga pokok penjualan telur puyuh, margin yang digunakan juga sebesar 15 persen. Sebagai perbandingan, digunakan juga margin keuntungan sebesar 20 persen. 
Tabel 1. Perhitungan harga pokok produksi usahatani jagung di Kabupaten Lampung Timur, 2016

\begin{tabular}{lcc}
\hline \multicolumn{1}{c}{ Uraian } & Satuan & Nilai (Rp) \\
\hline - Penerimaan & $\mathrm{Kg}$ & $\mathrm{A}$ \\
- Produksi & & \\
- Biaya Produksi & & \\
- Biaya Tunai & $\mathrm{Kg}$ & $\mathrm{B}$ \\
- Benih & $\mathrm{Kg}$ & $\mathrm{C}$ \\
- Pupuk & $\mathrm{Rp}$ & $\mathrm{D}$ \\
- Pestisida & $\mathrm{HOK}$ & $\mathrm{E}$ \\
- TK Luar Keluarga & & $\mathrm{F}=\mathrm{B}+\mathrm{C}+\mathrm{D}+\mathrm{E}$ \\
- Total Biaya Tunai & $\mathrm{HOK}$ & $\mathrm{G}$ \\
- Biaya Diperhitungkan & $\mathrm{Rp}$ & $\mathrm{H}$ \\
- TK Dalam Keluarga & $\mathrm{Rp}$ & $\mathrm{I}$ \\
- Penyusutan Alat & $\mathrm{Rp}$ & $\mathrm{J}$ \\
- Pajak & $\mathrm{Rp}$ & $\mathrm{K}$ \\
- Sewa Lahan & $\mathrm{Rp}$ & $\mathrm{L}=\mathrm{G}+\mathrm{H}+\mathrm{I}+\mathrm{J}+\mathrm{K}$ \\
- Biaya Lain-lain & $\mathrm{Rp}$ & $\mathrm{M}=\mathrm{F}+\mathrm{L}$ \\
- Total Biaya & & \\
Diperhitungkan & & \\
- Total Biaya & $\mathrm{Rp}$ & $\mathrm{F}-\mathrm{A}$ \\
- Pendapatan & & \\
- Pendapatan Atas Biaya & $\mathrm{M}-\mathrm{A}$ \\
Tunai & $\mathrm{Rp}$ & $\mathrm{M} / \mathrm{A}$ \\
- Pendapatan Atas Biaya & $\mathrm{Rp}$ & \\
Total & & \\
- Harga Pokok Produksi & & \\
Sumber : Sumodiningrat dan Isawara (1993) & \\
& &
\end{tabular}

\section{HASIL DAN PEMBAHASAN}

\section{Karakteristik Petani Responden}

Tingkat umur petani responden berkisar antara 2870 tahun dengan umur rata-rata 47 tahun. Jumlah responden terbanyak ada di kisaran umur antara 28-42 tahun (42,31 persen), yang berarti bahwa tenaga kerja yang ada di daerah penelitian merupakan tenaga kerja potensial dan masih dapat ditingkatkan lagi produktivitasnya (Mantra 2004). Tingkat pendidikan sebagian besar petani responden adalah SD dan SMP (44,23 persen). Pengalaman petani responden dalam berusahatani jagung di daerah penelitian cukup beragam, yaitu sebaran pengalaman paling rendah adalah 2 tahun dan pengalaman paling tinggi adalah 40 tahun.

Jumlah tanggungan keluarga petani responden sebagian besar adalah 2-5 jiwa (75,00 persen). Kondisi yang demikian menunjukkan bahwa keluarga petani di daerah penelitian menurut BKKBN tahun 2008 merupakan keluarga besar (jumlah anak $>2$ orang). Kepemilikan lahan petani jagung beragam, luas lahan paling sempit adalah 0,25 ha dan paling luas adalah 5 ha. Kepemilikan lahan di Desa Sidorejo rata-rata $0,25-1,82$ ha (59,61 persen dari keseluruhan responden). Kepemilikan lahan petani responden yang lebih dari 2 ha terdiri dari beberapa kapling.
Pendapatan petani dapat dibedakan menjadi dua yaitu pendapatan usahatani dan pendapatan rumah tangga (Gustiyana 2003). Pendapatan petani di luar kegiatan usahatani diperoleh dari pekerjaan sampingan, diantaranya sebagai wiraswasta (pedagang, bengkel, ojek) atau buruh. Petani jagung mengunakan benih yang beragam untuk melakukan usahatani jagung. Jenis benih yang banyak digunakan petani responden diantaranya Bisi-18, NK-33, Pioneer-27 dan DK-95. Seluruh petani responden di daerah penelitian merupakan anggota kelompok tani.

\section{Keragaan Usahatani Jagung}

Berdasarkan hasil penelitian di lapang, tanaman jagung di daerah penelitian ditanam secara monokultur. Sebagian besar petani di Desa Sidorejo melakukan penanaman jagung sebanyak 3 kali dalam satu tahun. Waktu penanaman jagung di daerah penelitian tidak serempak, sehingga waktu panen tidak bersamaan pula. Sebagian besar petani melakukan penanaman jagung musim tanam pertama pada bulan Desember-Maret, musim tanam kedua pada bulan April-Juli, dan musim tanam ketiga pada bulan Agustus-November setiap tahunnya.

Budidaya jagung di daerah penelitian yaitu didahului dengan persiapan lahan yang meliputi pembabatan atau pembersihan lahan dan pembentukan untuk pengairan. Kemudian tahap selanjutnya adalah pengolahan tanah dengan mencangkul tanah yang akan ditanami jagung. Penanaman dilakukan dengan menggunakan tugal (ditajuk) dengan kedalaman $\pm 5 \mathrm{~cm}$ dengan jarak tanam yang digunakan oleh rata-rata petani responden adalah $60 \mathrm{~cm} \times 20 \mathrm{~cm}$ atau $70 \mathrm{~cm}$ x 20 $\mathrm{cm}$ dengan jumlah benih rata-rata satu biji per lubang.

Kegiatan selanjutnya adalah pemupukan. Pemupukan dilakukan dua kali. Pemupukan tahap pertama dilakukan pada saat tanaman berumur 1015 hari dan tahap kedua dilakukan pada saat tanaman berumur 35-40 hari. Pemeliharaan dilakukan dengan cara penyiangan (memberantas gulma) yang dilakukan melalui penyemprotan dengan menggunakan herbisida. Jenis herbisida yang banyak digunakan oleh petani responden adalah Gramoxone, Roundup, Calaris, Bionasa dan Zenus, sedangkan untuk hama tikus petani responden menggunakan Pospit.

Pemanenan dilaksanakan pada waktu umur tanaman sekitar 90-100 hari setelah tanam (Bisi-18 
95-100 hst, NK-33 100 hst, Pioneer-27 100 hst, dan DK-95 100-125 hst). Kegiatan pemanenan ini yaitu dengan mengambil jagung yang masih dalam bentuk tongkol yang sudah tidak berkelobot dari pohonnya. Biasanya pada waktu pemanenan, petani (pemilik lahan) sudah didatangi oleh pemborong jagung dari daerah tersebut maupun dari luar daerah tersebut. Pemborong jagung tersebut membeli jagung masih dalam bentuk tongkol kering di pohon. Petani jagung menjual hasil panennya langsung dalam bentuk tongkol kering di pohon, karena petani tidak memiliki fasilitas untuk kegiatan pasca panen.

Benih jagung yang digunakan oleh petani responden di daerah penelitian semuanya menggunakan benih varietas hibrida yang diperoleh dari kios/toko pertanian. Jenis benih varietas hibrida yang digunakan antara lain Bisi18, NK-33, Pioneer-27, dan DK-95. Bisi-18 adalah benih jagung yang banyak dengan jumlah petani sebanyak 15 petani. Petani responden banyak menggunakan Bisi-18, karena jenis benih ini menghasilkan jagung dengan tongkol yang besar dan tahan terhadap penyakit bulai.

Pupuk yang banyak digunakan oleh petani jagung responden adalah pupuk urea, SP-36, dan NPK/Phonska. Harga pupuk yang berlaku di daerah penelitian satu tahun terakhir (2016) adalah pupuk urea sekitar Rp 2.000,00/kg-Rp 2.300,00/kg, pupuk SP-36 sekitar Rp 2.300,00/kg-Rp $2.400,00 / \mathrm{kg}$, dan pupuk NPK/Phonska sekitar Rp $2.400,00 / \mathrm{kg}$-Rp 2.600,00/kg. Penggunaan pupuk oleh responden petani jagung belum sesuai (kurang) dengan anjuran dari Balai Penyuluhan Pertanian Sekampung Udik (2016). Penggunaan pupuk urea terbanyak adalah pada usahatani jagung jenis benih Bisi-18 yaitu 219,07 kg/ha (anjuran BPP $450 \mathrm{~kg} / \mathrm{ha}$ ). Penggunaan pupuk NPK terbanyak adalah pada usahatani jagung jenis benih DK-95 yaitu 86,54 kg/ha (anjuran BPP 100 $\mathrm{kg} / \mathrm{ha}$ ). Dan penggunaan pupuk SP-36 terbanyak adalah pada usahatani jagung jenis benih NK-33 yaitu 89,89 (anjuran BPP $100 \mathrm{~kg} / \mathrm{ha}$ ).

Penggunaan herbisida dilakukan dengan sprayer atau tangki semprot. Penggunaan pestisida dimaksudkan untuk mempermudah pekerjaan petani, sehingga waktu yang digunakan lebih cepat dibandingkan dengan cara manual. Penggunaan pestisida jenis herbisida terbanyak adalah pada usahatani jagung jenis benih NK-33 dan Pioneer27 dengan total penggunaan herbisida sebanyak 2,25 $\mathrm{g} / \mathrm{lt}$, sedangkan penggunaan pestisida terendah pada usahatani jagung jenis benih Bisi-18 dengan total penggunaan herbisida sebanyak $1,88 \mathrm{~g} / \mathrm{lt}$. Penggunaan pestisida jenis rodentisida paling banyak digunakan pada usahatani jagung jenis benih NK-33 yaitu sebanyak 0,89 g/lt dan paling sedikit digunakan pada usahatani jenis benih DK95 yaitu sebanyak $0,72 \mathrm{~g} / \mathrm{lt}$.

Penggunaan tenaga kerja terdiri dari tenaga kerja dalam keluarga dan tenaga kerja luar keluarga. Tenaga kerja yang dicurahkan dalam usahatani jagung terdiri dari tenaga kerja pria dan wanita yang diukur setara dengan Hari Orang Kerja (HOK). Penyetaraan dilakukan berdasarkan upah dan jam kerja tenaga kerja pria dan wanita di Desa Sidorejo Kecamatan Sekampung Udik yang nilainya sama, yaitu antara Rp 55.000,00-Rp $60.000,00$ per hari dengan jam kerja 8 jam/hari. Rata-rata penggunaan tenaga kerja terbanyak adalah pada kegiatan pemanenan. Pada kegiatan pengolahan lahan dan pemanenan, tenaga kerja tidak diupah berdasarkan upah harian, melainkan bersifat borongan. Penggunaan tenaga kerja paling banyak pada usahatani jagung jenis NK-33, sedangkan pada usahatani jagung jenis benih DK95 penggunaan tenaga kerjanya paling sedikit.

\section{Analisis Biaya dan Pendapatan Usahatani Jagung}

Biaya dalam usahatani terdapat dua macam yaitu biaya tetap dan biaya variabel. Biaya tetap adalah biaya yang tidak berubah dengan adanya penambahan atau pengurangan jumlah output yang dihasilkan. Biaya variabel adalah biaya yang berubah sejalan dengan adanya penambahan atau pengurangan output yang dihasilkan. Biaya-biaya yang dikeluarkan dalam usahatani jagung dalam penelitian ini terdiri dari biaya tunai dan biaya diperhitungkan. Biaya tunai terdiri dari biaya sarana produksi seperti biaya untuk pembelian benih, pupuk, pestisida, upah tenaga kerja yang berasal dari luar keluarga dan biaya lain-lain.

Biaya lain-lain meliputi biaya yang digunakan pencarian informasi/transportasi (pulsa dan bensin untuk memperoleh benih, pupuk, dan pestisida) serta biaya untuk tempat menyimpan benih, pupuk, dan pestisida sebelum digunakan. Biaya diperhitungkan meliputi upah tenaga kerja dalam keluarga, penyusutan alat, pajak, dan sewa lahan. Biaya pajak termasuk kedalam biaya diperhitungkan, karena petani responden tidak membayar pajak atas lahan yang digunakan untuk melakukan usahatani jagung. 
Tabel 2. Biaya dan pendapatan rata-rata usahatani jagung di Desa Sidorejo Kecamatan Sekampung Udik Kabupaten Lampung Timur, 2016

\begin{tabular}{|c|c|c|c|c|}
\hline Uraian & BISI-18 & NK-33 & PIONEER-27 & DK-95 \\
\hline Produksi (Kg/ha) (Kadar air $\pm 28-40$ persen) & $8.318,51$ & $8.487,04$ & $8.501,41$ & $8.731,60$ \\
\hline Harga (Rp) & $1.756,46$ & $1.725,48$ & $1.743,16$ & $1.734,62$ \\
\hline Penerimaan (Rp) & $14.611 .120,42$ & $14.644 .180,34$ & 14.819.294,02 & 15.145.967,69 \\
\hline Biaya Total Tunai (Rp) & $4.611 .466,70$ & $4.630 .093,15$ & $5.172 .559,92$ & $5.126 .818,68$ \\
\hline Biaya Total Diperhitungkan (Rp) & $6.893 .062,84$ & $7.075 .944,93$ & 7.144.034,30 & $6.717 .777,39$ \\
\hline Biaya Total (Rp) & $11.504 .529,54$ & 11.706.038,08 & $12.316 .594,21$ & $11.844 .596,07$ \\
\hline \multicolumn{5}{|l|}{ Pendapatan } \\
\hline I. Pendapatan Atas Biaya Tunai (Rp) & $9.999 .653,72$ & $10.014 .087,19$ & $9.646 .734,10$ & 10.019.149,01 \\
\hline II. Pendapatan Atas Biaya Total (Rp) & $3.106 .590,88$ & $2.938 .142,26$ & $2.502 .699,81$ & $3.301 .371,62$ \\
\hline $\mathrm{R} / \mathrm{C}$ atas Biaya Total & 1,27 & 1,25 & 1,20 & 1,28 \\
\hline
\end{tabular}

Sewa lahan dimasukkan ke dalam biaya diperhitungkan, karena responden pada penelitian ini tidak ada yang menyewa lahan untuk kegiatan usahataninya. Pendapatan usahatani adalah selisih antara total penerimaan dikurangi dengan total biaya yang dikeluarkan oleh petani (Soekartawi 2002). Analisis pendapatan usahatani jagung dapat dilihat pada Tabel 2.

Berdasarkan hasil dari tabel tersebut diketahui bahwa produksi rata-rata per hektar keempat jenis benih belum mencapai produksi potensial dan masih dapat ditingkatkan lagi. Produksi jagung paling rendah adalah benih Bisi-18 yaitu 8.318,51 $\mathrm{Kg} / \mathrm{ha}$ (produksi potensialnya $12.000 \mathrm{Kg} / \mathrm{ha}$ ) dan paling tinggi adalah benih DK-95 yaitu 8.731,60 $\mathrm{Kg} / \mathrm{ha}$ (produksi potensialnya $12.000 \mathrm{Kg} / \mathrm{ha}$ ). Harga jual yang diterima oleh petani rata-rata $\mathrm{Rp}$ $1.700,00 / \mathrm{kg}$.

Total biaya yang dikeluarkan dari keempat jenis benih paling tinggi yaitu Pioneer-27 (Rp 12.316.594,21/ha) dan paling rendah yaitu Bisi-18 (Rp11.504.529,54/ha). Total biaya benih Piooner27 yang tinggi disebabkan oleh biaya tunai dan biaya diperhitungkan yang tinggi. Biaya tunai benih DK-95 juga tinggi, akan tetapi biaya diperhitungkannya rendah, sehingga total biaya yang dikeluarkan tidak terlalu tinggi. Biaya yang dikeluarkan petani dapat ditekan, jika petani mendapatkan subsidi untuk input yang digunakan dalam usahatani jagung serta kemudahan dalam memperoleh pupuk. Selain biaya yang dapat ditekan, produksi juga dapat ditingkatkan.

Nisbah penerimaan atas biaya total berkisar antara 1,20-1,28 dengan nisbah penerimaan terkecil yaitu benih Pioneer-27 $(1,20)$ dan tertinggi yaitu benih DK-95 $(1,28)$. Nisbah penerimaan ini artinya setiap $\mathrm{Rp} 1,00$ yang dikeluarkan akan menghasilkan penerimaan sebesar nilai nisbah tersebut.

\section{Analisis Harga Pokok Produksi}

Harga pokok produksi usahatani adalah jumlah seluruh biaya yang dikeluarkan oleh petani dalam memproduksi komoditas persatuan output. Salah satu manfaat dari penentuan harga pokok produksi menurut Mulyadi (2007) yaitu untuk menentukan berapa besarnya harga jual produk. Oleh karena itu, perhitungan harga pokok produksi jagung adalah dengan membagi total biaya produksi dengan jumlah produksi dalam satu kali musim tanam. Harga pokok produksi suatu usahatani sangat penting diketahui, karena dengan diketahuinya harga pokok usahatani, maka petani dapat menentukan harga jual hasil produksinya dan dapat digunakan untuk menentukan berapa besarnya keuntungan yang diinginkan.

Analisis harga pokok produksi jagung (kadar air 28-40 persen) di Desa Sidorejo Kecamatan Sekampung Udik Kabupaten Lampung Timur dibedakan berdasarkan jenis benih yang digunakan oleh petani responden. Jenih benih yang digunakan oleh petani responden antara lain Bisi-18, NK-33, Pioneer-27 dan DK-95.

Berdasarkan Tabel 3, produksi rata-rata setiap benih jagung berbeda-beda dan belum mencapai produksi potensial setiap jenis benih. Produksi rata-rata jenis benih Bisi-18 yaitu 8.318,51 Kg/ha (produksi potensial $12.000 \mathrm{Kg} / \mathrm{ha}$ ), benih NK-33 yaitu $8.487,04 \mathrm{Kg} / \mathrm{Ha}$ (produksi potensial 10.120 $\mathrm{Kg} / \mathrm{ha}$ ), benih Pioneer yaitu $8.501,41 \mathrm{Kg} / \mathrm{ha}$ (produksi potensial $11.000 \mathrm{Kg} / \mathrm{ha}$ ) dan benih DK95 yaitu 8.731,60 $\mathrm{Kg} / \mathrm{ha}$ (produksi potensial $12.000 \mathrm{Kg} / \mathrm{ha})$. 
Tabel 3. Perhitungan harga pokok produksi jagung di Desa Sidorejo Kecamatan Sekampung Udik Kabupaten Lampung Timur, 2016

\begin{tabular}{lrrrr}
\hline \multicolumn{1}{c}{ Uraian } & \multicolumn{1}{c}{ BISI-18 } & NK-33 & PIONEER-27 & \multicolumn{1}{c}{ DK-95 } \\
\hline Harga Pokok Produksi (Rp) & $1.383,00$ & $1.379,28$ & $1.448,77$ & $1.359,52$ \\
Margin (15 persen) & 207,45 & 206,89 & 217,32 & 203,48 \\
Harga Pokok Penjualan (Rp) & $1.590,45$ & $1.586,18$ & $1.666,09$ & $1.560,00$ \\
Margin (20 persen) & 276,60 & 275,86 & 289,75 & 271,30 \\
Harga Pokok Penjualan (Rp) & $1.659,60$ & $1.655,14$ & $1.738,53$ & $1.627,82$ \\
Harga Jual Petani (Rp) & $1.756,46$ & $1.725,48$ & $1.743,16$ & $1.734,62$ \\
Harga Acuan Pembelian di Petani (Peraturan Menteri & $2.750-2.500$ & $2.750-2.500$ & $2.750-2.500$ & $2.750-2.500$ \\
Perdagangan RI) (Kadar air 30 - 35 persen) (Rp) & & & &
\end{tabular}

Harga pokok produksi jagung per kilogram dengan kadar air $\pm 28-40$ persen dari keempat jenis benih jagung, hanya benih Pioneer-27 yang memiliki harga pokok produksi tertinggi (Rp $1.448,77)$. Benih yang lainnya hanya Rp $1.300,00$ per kilogram. Hal ini terjadi karena biaya yang dikeluarkan untuk usahatani benih Pioneer lebih besar dibandingkan dengan benih yag lainnya. Harga pokok produksi ini dapat ditekan lebih kecil dengan cara pemerintah memfasilitasi petani untuk memudahkan mendapatkan input dan mensubsidi input.

Input yang digunakan petani jagung selain harganya yang mahal, sulit untuk diperoleh terutama untuk kebutuhan pupuk. Petani membutuhkan pupuk dalam jumlah banyak dalam melakukan usahatani. Akan tetapi, jumlah yang tersedia (subsidi) sangat terbatas, sehingga petani harus bersaing untuk mendapatkan pupuk subsidi. Jika petani membeli pupuk nonsubsidi harganya yang mahal, membuat petani kesulitan untuk mendapatkan pupuk.

Hasil penelitian ini didukung oleh penelitian Budiman (2011) yang mengatakan bahwa harga pokok produksi jagung berkadar air antara 28-40 persen tinggi. Hasil penelitian ini diperoleh bahwa harga jual jagung berkadar air antara 28-40 persen murah.

\section{Analisis Uji Beda Harga Pokok Produksi}

Pada analisis harga pokok produksi dilakukan uji one way anova untuk mengetahui apakah terdapat perbedaan antar jenis benih jagung dengan harga pokok produksi jagung. Berdasarkan pada hasil yang diperoleh pada test of homogeneity of variances, dimana dihasilkan bahwa probabilitas atau signifikaninya adalah 0,586 yang berarti lebih besar dari 0,05 maka dapat disimpulkan bahwa hipotesis nol (Ho) diterima, yang berarti asumsi bahwa ketiga varian populasi adalah sama (homogen) dapat diterima. Keempat varian yang sama tersebut, kemudian dilakukan uji anova. Berdasarkan hasil pengolahan data dengan menggunakan SPSS 20 diperoleh hasil uji one way anova yang disajikan pada Tabel 4 .

Hasil uji $\mathrm{F}$ hitung harga pokok produksi dan jenis benih jagung yaitu 1,586 dengan tingkat kepercayaan lebih dari $\alpha(0,205>0,05)$, maka $\mathrm{H}_{0}$ diterima yang berarti bahwa tidak terdapat perbedaan antara harga pokok produksi dan jenis benih jagung. Jenis benih jagung yang digunakan oleh petani responden tidak mempengaruhi harga pokok produksi yang dikeluarkan oleh petani responden. Biaya yang dikeluarkan petani dalam melakukan usahatani jagung meskipun menggunakan jenis benih jagung yang berbeda tidak berbeda jauh.

Kesimpulan menunjukkan $\mathrm{H}_{0}$ diterima, oleh karena itu dilakukan tes Pos Hoc. Post Hoc dilakukan untuk mengetahui kelompok mana yang berbeda dan yang tidak berbeda harga pokok produksinya. Dari hasil tes Pos Hoc (Tabel 5) tersebut diperoleh hasil bahwa terdapat perbedaan hanya pada benih Pioneer-27 dengan NK-33, sedangkan untuk benih yang lainnya menunjukkan adanya persamaan. Perbedan benih NK-33 dan Pioneer-27 sebesar 9376.61538 dengan taraf kepercayaan sebesar 96,10 persen.

Tabel 4. Hasil uji one way anova harga pokok produksi dan jenis benih jagung di Desa Sidorejo Kecamatan Sekampung Udik Kabupaten Lampung Timur

\begin{tabular}{lcrccc}
\hline & Sum of Squares & df & Mean Square & F & Sig. \\
\hline Between Groups & 603616837.154 & 3 & 201205612.385 & 1.586 & .205 \\
Within Groups & 6090424003.538 & 48 & 126883833.407 & & \\
\hline Total & 6694040840.692 & 51 & & & \\
\hline
\end{tabular}


Tabel 5. Hasil tes pos hoc harga pokok produksi jagung

\begin{tabular}{llrrrrr}
\hline \multirow{2}{*}{ (I) Jenis Benih } & \multicolumn{2}{c}{$(\mathrm{J})$ Jenis Benih } & $\begin{array}{c}\text { Mean Difference } \\
(\mathrm{I}-\mathrm{J})\end{array}$ & \multirow{2}{*}{ Std. Error } & \multirow{2}{*}{ Sig. } & \multicolumn{2}{c}{ 95\% Confidence Interval } \\
\cline { 5 - 7 } BISI-18 & NK-33 & 3577.53846 & 4418.21115 & .422 & -5305.8704 & 12460.9474 \\
& PIONEER-27 & -5799.07692 & 4418.21115 & .196 & -14682.4858 & 3084.3320 \\
& DK-95 & 742.30769 & 4418.21115 & .867 & -8141.1012 & 9625.7166 \\
NK-33 & BISI-18 & -3577.53846 & 4418.21115 & .422 & -12460.9474 & 5305.8704 \\
& PIONEER-27 & $-9376.61538^{*}$ & 4418.21115 & .039 & -18260.0243 & -493.2065 \\
& DK-95 & -2835.23077 & 4418.21115 & .524 & -11718.6397 & 6048.1781 \\
PIONEER-27 & BISI-18 & 5799.07692 & 4418.21115 & .196 & -3084.3320 & 14682.4858 \\
& NK-33 & $9376.61538^{*}$ & 4418.21115 & .039 & 493.2065 & 18260.0243 \\
& DK-95 & 6541.38462 & 4418.21115 & .145 & -2342.0243 & 15424.7935 \\
DK-95 & BISI-18 & -742.30769 & 4418.21115 & .867 & -9625.7166 & 8141.1012 \\
& NK-33 & 2835.23077 & 4418.21115 & .524 & -6048.1781 & 11718.6397 \\
& PIONEER-27 & -6541.38462 & 4418.21115 & .145 & -15424.7935 & 2342.0243 \\
\hline
\end{tabular}

Tabel 6. Perhitungan harga pokok penjualan jagung di Desa Sidorejo Kecamatan Sekampung Udik Kabupaten Lampung Timur, 2016

\begin{tabular}{|c|c|c|c|c|}
\hline Uraian & BISI-18 & NK-33 & Pioneer-27 & DK-95 \\
\hline Harga Pokok Produksi (Rp) & $1.383,00$ & $1.379,28$ & $1.448,77$ & $1.359,52$ \\
\hline Margin (15,00 persen) & 207,45 & 206,89 & 217,32 & 203,48 \\
\hline Harga Pokok Penjualan (Rp) & $1.590,45$ & $1.586,18$ & $1.666,09$ & $1.560,00$ \\
\hline Margin (20,00 persen) & 276,60 & 275,86 & 289,75 & 271,30 \\
\hline Harga Pokok Penjualan (Rp) & $1.659,60$ & $1.655,14$ & $1.738,53$ & $1.627,82$ \\
\hline
\end{tabular}

\section{Harga Pokok Penjualan}

Harga jual adalah sejumlah kompensasi yang dibutuhkan untuk mendapatkan sejumlah kombinasi barang atau jasa. Penetapan harga jual adalah harapan agar produk yang telah diproduksi laku terjual dan mendapatkan laba atau keuntungan. Menurut Mulyadi (2001), pada prinsipnya harga jual harus dapat menutupi biaya penuh ditambah dengan laba yang wajar. Harga jual sama dengan harga pokok produksi ditambah dengan margin keuntungan.

Pada penelitian ini dihitung berapa harga jual jagung yang seharusnya diterima oleh petani jagung responden dalam menjual hasil produksinya. Perhitungan harga pokok penjualan ini dilakukan dengan penambahan harga pokok produksi dengan margin keuntungan. Margin keuntungan yang digunakan sebesar 15,00 persen dengan menggunakan pertimbangan tingkat inflasi $(0,70$ persen $)$ dan suku bunga $(17,50$ persen) yang berlaku tahun 2016 .

Berdasarkan Tabel 6 dapat dilihat bahwa harga pokok penjualan jagung dari beberapa benih berbeda-beda. Akan tetapi, selisih harga pokok penjualan antar jenis benih jagung tidak berbeda jauh satu sama lain. Harga pokok penjualan tertinggi dengan margin keuntungan 15,00 persen adalah jagung benih Pioneer-27 dengan harga pokok penjualan sebesar $\mathrm{Rp} 1.666,09$. Harga pokok penjualan jagung terendah adalah jagung benih DK-95 dengan harga pokok penjualan sebesar Rp 1.560,00. Jika dibandingkan dengan harga pokok penjualan yang menggunakan margin keuntungan 20,00 persen harga pokok produksi yang diperoleh lebih mendekati harga jual yang

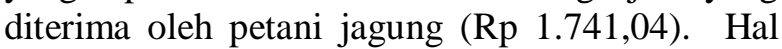
ini berarti bahwa petani jagung responden dari keempat jenis benih yang digunakan sudah memperoleh keuntungan, karena harga jual yang mereka terima di atas perhitungan harga pokok penjualan dengan margin keuntungan 15,00 persen maupun 20,00 persen.

\section{KESIMPULAN}

Berdasarkan pembahasan tersebut dapat diambil kesimpulan yaitu harga pokok produksi jagung per kilogram yaitu sebesar Rp 1.383,00 untuk Bisi-18, Rp 1.379,28 untuk NK-33, Rp 1.448,77 untuk Pioneer-27 dan Rp 1.359,52 untuk DK-95. Harga pokok penjualan jagung per kilogram dengan margin keuntungan 15,00 persen untuk jenis benih Bisi-18 sebesar Rp 1.590,45, Rp $1.586,18$ untuk NK-33, Rp 1.666,09 untuk Pioneer-27 dan Rp 1.560,00 untuk DK-95. Jadi, 
usahatani jagung di Desa Sidorejo Kecamatan Sekampung Udik Kebupaten Lampung Timur sudah menguntungkan (dilihat dari harga jual petani responden sebesar Rp 1.741,04 meskipun masih di bawah harga harga acuan pembelian menurut Peraturan Menteri Perdagangan RI) serta $\mathrm{R} / \mathrm{C}$ rata-rata di atas 1,20 yang berarti bahwa setiap $\mathrm{Rp} \quad 1,00$ yang dikeluarkan akan menghasilkan $\mathrm{Rp} 1,20$. Tidak ada perbedaan harga pokok produksi antar keempat merek benih jagung yang ditanam oleh petani responden.

\section{DAFTAR PUSTAKA}

BPP [Balai Penyuluhan Pertanian] Sekampung Udik. 2016. Anjuran pupuk. BPP Sekampung Udik. Pugung Raharjo.

BPS [Badan Pusat Statistik] Provinsi Lampung. 2016. Lampung dalam Angka. BPS Provinsi Lampung. Bandar Lampung.

BRI [Bank Rakyat Indonesia] Provinsi Lampung. 2016. Suku bunga bank. BRI Provinsi Lampung. Lampung.

Budiman A. 2011. Analisis efisiensi pemasaran dan harga pokok produksi [HPP] jagung pada berbagai jenis kadar air di Kecamatan Jati Agung Kabupaten Lampung Selatan. Skripsi. Universitas Lampung. Bandar Lampung.

Falatehan dan Wibowo. 2008. Analisis keunggulan komparatif dan kompetitif pengusahaan komoditi jagung di Kabupaten Grobogan. Jurnal Agribisnis dan Ekonomi Pertanian, 2 (1) : 1-15. http://media.neliti. com/media/publications/9372-id-analisis-keu nggulan-komparatif-dan-kompetitif-pengusah a-jagung-di-kab.pdf\&sa=u\&ved=2ahukewiy 1 e_svtnzahubni8khvnwc8uqfjaaegqicrab\&usg =a0vvaw2i0lvineu372ti66dgdhvp.

November 2015].

Gustiyana H. 2003. Analisis Pendapatan Usahatani untuk Produk Pertanian. Salemba Empat. Jakarta.

Keputusan Gubernur Provinsi Lampung. 2010. Harga Minimum Regional (HMR). Gubernur Provinsi Lampung. Bandar Lampung.

Koutsoyiannis A. 1979. Modern Microeconomics. The Mac Millan Press Ltd. Second Edition.

Mantra IB. 2004. Demografi Umum. Pustaka Pelajar. Yogyakarta.

Mulyadi. 2001. Akuntansi Manajemen Konsep, Manfaat, dan Rekayasa. Salemba. Jakarta. Jakarta.

Putra GM. 2014. Sistem penetapan harga pokok penjualan telur puyuh (Coturnix-Coturnix Japonica) pada usaha ternak puyuh (Studi kasus di Peternakan Puyuh Soreang Kabupaten Bandung). Student E-Journal, 3 (4) : 1-11. http://jurnal.unpad.ac.id/ejournal /article/view/6117.3168 [10 November 2015].

Rosalia F. 2010. Analisis Pendapatan Usahatani Dan Pemasaran Jagung Varietas Hibrida Pada Lahan Sawah Irigasi di Kecamatan Palas Kabupaten Lampung Selatan. Skripsi. Universitas Lampung. Bandar Lampung.

Soekartawi. 2002. Analisis Usahatani. Universitas Indonesia. Jakarta.

Sugiarto. 2005. Ekonomi Mikro Sebuah Kajian Komprehansif. Gramedia Pustaka Utama. Jakarta.

Sumodiningrat G dan LA Iswara. 1993. Ekonomi Produksi. Karunia Jakarta Universitas Terbuka. Jakarta. 